\title{
Bariery dyfuzyjne zapobiegające kruchości połączeń lutowanych aluminium z innymi metalami
}

\section{Diffusion barriers to prevent of the fragility soldered joints aluminum with other metals}

\section{Streszczenie}

Stale rosnące zapotrzebowanie na nowoczesne urządzenia, potrafiące sprostać coraz bardziej rosnącym wymogom ekologicznym i ekonomicznym, w różnych gałęziach przemysłu, takich jak np. przemysł energetyczny, chłodniczy, grzewczy czy też klimatyzacyjny spowodowały, że coraz większego znaczenia nabiera możliwość spajania ze sobą materiałów różniących się znacznie między sobą zarówno pod względem właściwości fizykochemicznych, jak i mechanicznych. Do tej grupy połączeń zalicza się połączenia lutowane aluminium z innymi metalami, takimi jak: miedź, stal niestopowa i stopowa. Zróżnicowane właściwości fizykochemiczne i mechaniczne nie są jednak jedynymi problemami występującymi podczas spajania tych materiałów. Istnieje bowiem niebezpieczeństwo tworzenia się twardych faz międzymetalicznych powodujących kruchość połączeń lutowanych.

W artykule przedstawiono sposób ograniczenia występowania faz międzymetalicznych na granicy połączenia aluminium $z$ innymi metalami, przez naniesienie na ich powierzchnie warstw: $\mathrm{Zn}, \mathrm{Zn}-\mathrm{Ni}$, Cu-Sn-Zn oraz Ni, metodami galwanicznymi. Przedstawiono wyniki pomiarów zwilżalności i rozpływności lutów cynkowych na podłożach z naniesionymi warstwami, a także badania metalograficzne, pomiary mikrotwardości oraz wytrzymałości na ścinanie połączeń lutowanych.
Prof. dr hab. inż. Zbigniew Mirski, mgr inż. Tomasz Wojdat, dr inż. Tomasz Piwowarczyk, dr inż. Mateusz Stachowicz - Politechnika Wrocławska.

\section{Abstract}

The ever-increasing demand for modern equipment, to meet the growing ecological and economical requirements, in a variety of industries such as the power plant, cooling, heating or air conditioning meant more and more importance to the possibility of bonding together materials with differ significantly in among themselves in terms of the physicochemical properties and mechanical properties. This group of joints includes aluminum solder joints with other metals such as copper, alloy and non-alloy steel. The different physicochemical and mechanical properties are not the only problems that occur during the bonding of these materials. There is a danger of the formation of hard intermetallic phases resulting fragility of solder joints.

This article shows the method to reduce the occurrence of intermetallic phases on the border of a combination of aluminum with other metals, by applying to the surface layers of $\mathrm{Zn}, \mathrm{Zn}-\mathrm{Ni}, \mathrm{Cu}-\mathrm{Sn}-\mathrm{Zn}$ and $\mathrm{Ni}$ electroplating methods. The results of measurements of flowing solder wettability and zinc on substrates with added layers and metallographic examination, microhardness measurements and shear strength of solder joints.

\section{Wstęp}

Uzyskanie funkcjonalnych połączeń lutowanych uwarunkowane jest zajściem podstawowych zjawisk fizykochemicznych na powierzchni materiału podstawowego, czyli zapewnienie możliwie jak najlepszej zwilżalności i związanej z nią rozpływności, co w konsekwencji umożliwia zajście zjawisk kapilarnych 
i szczelne wypełnienie szczeliny lutowniczej ciekłym lutem. Jakość złącza lutowanego jest zatem w dużej mierze uzależniona od właściwego doboru materiałów dodatkowych do lutowania płomieniowego, tj. lutów i topników. O ile w przypadku połączeń jednoimiennych nie stanowi to zwykle większego problemu, o tyle dobór odpowiednich materiałów dodatkowych do wykonywania połączeń różnoimiennych jest już dużo bardziej skomplikowany i stwarza często wiele problemów. Spowodowane jest to brakiem uniwersalnych lutów i topników dobrze zwilżających powierzchnię szerokiej grupy materiałów. Szczególnie jest to utrudnione w przypadku połączeń różnoimiennych z aluminium, które jest trudno lutowalnym materiałem inżynierskim,

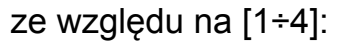

- stosunkowo niską temperaturę topnienia aluminium (ok. $660^{\circ} \mathrm{C}$ ), utrudniającą dobór spoiwa,

- obecność na powierzchni trudno topliwej $\left(2050^{\circ} \mathrm{C}\right)$, trwałej chemicznie $\left(1116,3 \mathrm{~kJ} / \mathrm{mol} \mathrm{O} \mathrm{O}_{2}\right)$, trudno zwilżalnej przez luty i szczelnej warstewki tlenków $\mathrm{Al}_{2} \mathrm{O}_{3}$,

- małe właściwości wytrzymałościowe, zwłaszcza w temperaturze powyżej $500^{\circ} \mathrm{C}$,

- dużą przewodność $(237 \mathrm{~W} / \mathrm{m} \cdot \mathrm{K})$ i rozszerzalność cieplną $\left(26 \cdot 10^{-6} 1 / \mathrm{K}\right)$ oraz znaczny skurcz objętościowy $(7 \%)$ - sprzyjające występowaniu naprężeń i odkształceń cieplnych.

Spoiwa typu Zn-Al, stosowane do lutowania miękkiego, dobrze zwilżają powierzchnię aluminium EN AW-1050A oraz stali niestopowej DC01 i kwasoodpornej X5CrNi18-10. Nie zapewniają wystarczającej zwilżalności podłoża miedzianego M1E [4].

Niedostateczna zwilżalność miedzi lutami cynkowymi nie stanowi jedynego problemu. Jak podano w pracy [4], na granicy połączenia lutów Zn z miedzią M1E oraz stalą DC01 tworzą się twarde strefy reakcyjne powodujące kruchość połączeń lutowanych z aluminium.

Przewidywanym rozwiązaniem problemu kruchości różnoimiennych połączeń lutowanych z aluminium może być zastosowanie powłok galwanicznych, o odpowiedniej grubości, stanowiących barierę dyfuzyjną.
W pracy [3] wykazano, że zastosowanie warstwy Zn o grubości $20 \mu \mathrm{m}$ naniesionej na powierzchnię stali niestopowej metodą cynkowania płomieniowego skutecznie ogranicza tworzenie się strefy reakcyjnej na granicy połączenia z lutem. Ponadto przewidywanym efektem zastosowania powłok galwanicznych jest poprawa zwilżalności miedzi M1E spoiwami cynkowymi.

\section{Materiały do badań}

Podstawowym materiałem stosowanym w badaniach było aluminium w EN AW-1050A wg PN-EN 573-3:2010 o składzie chemicznym podanym w tablicy I [7].

Do wykonywania różnoimiennych połączeń lutowanych z aluminium wybrano: miedź M1E oraz stal niestopową DC01, których skład chemiczny przedstawiono

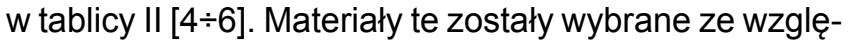
du na występowanie stref reakcyjnych na granicy połączenia z lutami cynkowymi [4].

Połączenia lutowane aluminium z tymi metalami wykonano przy użyciu spoiw Zn-Al, o zawartości Al zwykle nieprzekraczającej $15 \%$ wag. [1, 2, 4]. Skład chemiczny, temperaturę topnienia oraz postać stosowanych lutów Zn-Al przedstawiono w tablicy III. Do lutowania używano również niekorozyjnego topnika o oznaczeniu 192 NX firmy Castolin, zawierającego związki cezu, w postaci pasty. Temperatura aktywności topnika 192 NX mieści się w zakresie $420 \div 470^{\circ} \mathrm{C}[14]$.

\section{Powłoki galwaniczne do lutowania $z$ aluminium}

Głównym zadaniem powłok galwanicznych było wyeliminowanie, przez utworzenie bariery dyfuzyjnej, kruchych faz międzymetalicznych tworzących się na

Tablica I. Skład chemiczny aluminium EN AW-1050A [7]

Table I. The chemical composition of the aluminum grade EN AW-1050A [7]

\begin{tabular}{|c|c|c|c|c|c|c|c|c|c|c|c|}
\hline \multicolumn{3}{|c|}{ Oznaczenie } & \multicolumn{10}{c|}{ Skład chemiczny, \% wag. } \\
\hline PN & EN & $\begin{array}{c}\mathrm{Al} \\
\min \end{array}$ & $\begin{array}{c}\mathrm{Fe} \\
\max \end{array}$ & $\begin{array}{c}\mathrm{Si} \\
\max \end{array}$ & $\begin{array}{c}\mathrm{Zn} \\
\max \end{array}$ & $\begin{array}{c}\mathrm{Ti} \\
\max \end{array}$ & $\begin{array}{c}\mathrm{Mg} \\
\max \end{array}$ & $\begin{array}{c}\mathrm{Mn} \\
\max \end{array}$ & $\begin{array}{c}\mathrm{Cu} \\
\max \end{array}$ & $\begin{array}{c}\mathrm{Ni} \\
\max \end{array}$ & $\begin{array}{c}\text { Inne } \\
\max \end{array}$ \\
\hline A1 & EN AW-1050A & 99,5 & 0,40 & 0,25 & 0,07 & 0,05 & 0,05 & 0,05 & 0,05 & 0,05 & 0,03 \\
\hline
\end{tabular}

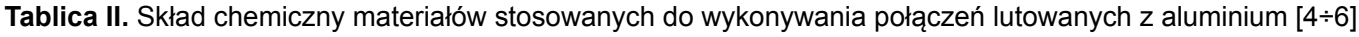

Table II. The chemical composition of the materials used to made of soldered joints witch aluminum $[4 \div 6]$

\begin{tabular}{|c|c|c|c|}
\hline \multicolumn{4}{|c|}{ Miedź M1E wg PN-H-82120:1977 - Skład chemiczny, \% wag. } \\
\hline Cu & Bi max & Pb max & Inne max \\
\hline 99,90 & 0,001 & 0,005 & 0,004 \\
\hline \multicolumn{3}{|c|}{ Stal niestopowa DC01 wg PN-EN10130:2009 - Skład chemiczny, \% wag., reszta Fe } \\
\hline C & Mn & P & S \\
\hline
\end{tabular}


Tablica III. Skład chemiczny, temperatura topnienia oraz postać stosowanych lutów cynkowych [4, 8]

Table III. The chemical composition, melting point and the form of used zinc solders $[4,8]$

\begin{tabular}{|c|c|c|c|c|}
\hline \multirow{2}{*}{ Oznaczenie lutu } & \multicolumn{2}{|c|}{ Skład chemiczny, \% wag. } & \multirow{2}{*}{ Zakres temp. topnienia, ${ }^{\circ} \mathrm{C}$} & Postać, wymiary, mm \\
\cline { 2 - 3 } & $\mathrm{Zn}$ & $\mathrm{Al}$ & $382 \div 407$ & drut $\varnothing 1,6$ \\
\hline L-ZnAl2 & 98 & 2 & $382 \div 387$ & drut $\varnothing 1,6$ \\
\hline L-ZnAl4 & 96 & 4 & $382 \div 450$ & drut $\varnothing 1,0$ \\
\hline L-ZnAl15 & 85 & 15 & \\
\hline
\end{tabular}

granicy różnoimiennych połączeń lutowanych z aluminium, wykonanych spoiwami cynkowymi. Naniesione warstwy powinny również charakteryzować się dobrymi właściwościami lutowniczymi, tzn. zapewnić dobrą zwilżalność oraz rozpływność spoiw stosowanych w badaniach.

Nanoszenie powłok galwanicznych było poprzedzone odpowiednim przygotowaniem powierzchni pokrywanych materiałów w celu zapewnienia odpowiedniej adhezji mechanicznej warstwy z danym podłożem. Na podstawie analizy literaturowej oraz według zaleceń firm specjalizujących się w galwanotechnice, przed przystąpieniem do nanoszenia powłok galwanicznych należy najpierw odtłuścić chemicznie powierzchnię, następnie poddać ją trawieniu w roztworze kwasu solnego i ponownie poddać odtłuszczaniu, z tym że anodowo-katodowemu. Przygotowanie powierzchni metali pod powłoki odbywało się według schematu przedstawionego na rysunku 1 [9]. Wyniki pomiarów chropowatości powierzchni próbek, uzyskanej po przeprowadzonym procesie przygotowawczym, zawarto w tablicy IV.

$\mathrm{Na}$ podstawie analizy literaturowej oraz po konsultacjach z AGA-TEC, dokonano wyboru czterech rodzajów

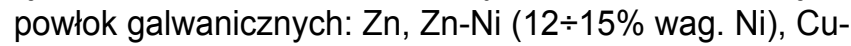
$\mathrm{Sn}-\mathrm{Zn}$ (tzw. biały brąz) oraz Ni. Nakładanie wybranych powłok przeprowadzono na stanowisku przedstawionym na rysunku 2.

\section{Powłoka cynkowa (Zn)}

Nakładanie powłoki cynkowej odbywało się w alkalicznej kąpieli o technicznej nazwie Envirozin 120. W zlewce szklanej o pojemności $1 \mathrm{dm}^{3}$ wypełnionej kąpielą Zn Envirozin 120 zanurzono anodę w postaci krążka z niklowanej blachy oraz materiał, na który naniesiona miała zostać powłoka, stanowiący katodę. Stosunek pola powierzchni anody do katody wynosił 2:1. Zagwarantowanie równomiernej wymiany elektrolitu wymagało zastosowania ciągłego mieszania

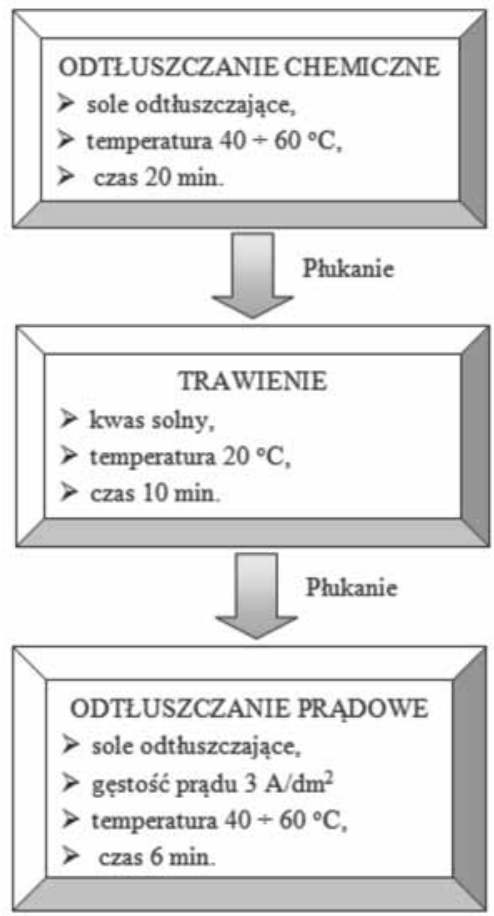

Rys. 1. Schemat procesu przygotowania powierzchni stali przed nanoszeniem powłok [9]

Fig. 1. Diagram of steel surface preparation prior to application of coatings [9]

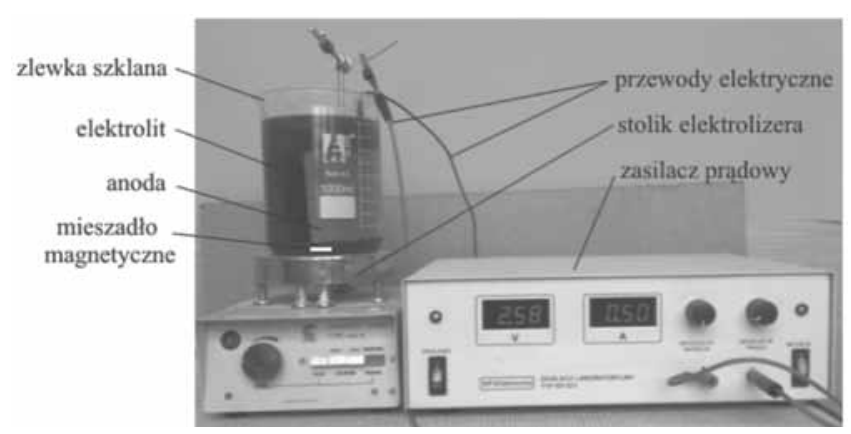

Rys. 2. Stanowisko do elektrolitycznego nanoszenia powłok Fig. 2. Stand for electrolytic coating

Tablica IV. Wyniki pomiarów chropowatości powierzchni materiałów przed przystąpieniem do procesu nanoszenia powłok galwanicznych Table IV. The results of the measurements surface roughness materials before accession to the process of jetting galvanic coatings

\begin{tabular}{|c|c|c|c|c|}
\hline \multirow{2}{*}{ Materiał } & \multirow{2}{*}{ Stan } & \multicolumn{3}{|c|}{ Chropowatość powierzchni, $\mu \mathrm{m}$} \\
\cline { 2 - 5 } & & $\mathrm{Ra}$ & $\mathrm{Rz}$ & $\mathrm{Rt}$ \\
\hline \multirow{2}{*}{ Miedź M1E } & surowy & 0,20 & 1,34 & 2,01 \\
\cline { 2 - 5 } & po obróbce & 0,18 & 1,42 & 2,02 \\
\hline \multirow{2}{*}{ Stal niestopowa DC01 } & surowy & 0,75 & 4,96 & 8,76 \\
\cline { 2 - 5 } & po obróbce & 0,99 & 5,14 & 9,32 \\
\hline
\end{tabular}


kapieli ruchem obrotowym mieszadła magnetycznego obracającego się z prędkością 60 obr/min. Parametry pracy kąpieli Zn Envirozin 120 pracującej w układzie zawieszkowym przedstawiono w tablicy $\mathrm{V}$ [9].

Po nałożeniu powłoki $\mathrm{Zn}$ należało poddać ją rozjaśnianiu w 0,5\% roztworze $\mathrm{NHO}_{3}$ w celu jej aktywowania, a następnie pasywacji w kąpieli chromianowej, o nazwie TriPass ELV 5200, w celu zwiększenia jej odporności korozyjnej.

Parametrem decydującym o grubości otrzymanych powłok, przy utrzymaniu stałej wartości temperatury kąpieli oraz katodowej gęstości prądu, jest czas ich nakładania. Maksymalna szybkość nakładania powłoki cynkowej wynosi $0,5 \mu \mathrm{m} / \mathrm{min}$ dla temperatury kąpieli wynoszącej $30^{\circ} \mathrm{C}$ oraz katodowej gęstości prądu równej $3 \mathrm{~A} / \mathrm{dm}^{2}$ [9]. Zalecana grubość nakładanych galwanicznie powłok Zn wynosi od 6 do $25 \mu \mathrm{m}$. Do prób lutowania nakładano powłoki Zn o grubości $20 \mu \mathrm{m}$.

\section{Powłoka stopowa cynkowo-niklowa (Zn-Ni)}

Nakładanie stopowej powłoki Zn-Ni odbywało się w alkalicznej kąpieli o technicznej nazwie Enviralloy $\mathrm{Ni}$ 12-15, w której udział niklu mieści się w przedziale od 12 do $15 \%$ wag. Powłokę Enviralloy Ni 12-15 nakładano w taki sam sposób jak powłokę Zn, zmieniając jedynie parametry prądowe (tabl. VI). Maksymalna prędkość osadzania powłoki Zn-Ni dla temperatury kąpieli wynoszącej $28^{\circ} \mathrm{C}$ i katodowej gęstości prądu równej $2 \mathrm{~A} / \mathrm{dm}^{2}$ wynosiła $0,18 \mu \mathrm{m} / \mathrm{min}$ [10].

Po nałożeniu powłoki Zn-Ni należało poddać ją rozjaśnianiu w $1 \div 2 \%$ roztworze $\mathrm{HCl}$ w celu jej aktywowania, a następnie pasywacji w kąpieli chromianowej, o nazwie TriPass ELV 3100, w celu nadania powłoce niebieskawego koloru i zapewnienia jej dużej odporności na korozję dziesięciokrotnie przewyższającej odporność korozyjną powłok Zn.
Zalecana grubość powłok Zn-Ni wynosi od 12 do $16 \mu \mathrm{m}$. Do prób lutowania nakładano powłoki Zn-Ni o grubości $16 \mu \mathrm{m}$.

\section{Powłoka stopowa Cu-Sn-Zn (tzw. biały brąz)}

Nakładanie powłok Cu-Sn-Zn jest cyjankalicznym procesem nakładania powłok białego brązu, zawierających w \% wag. ok. 53\% Cu, 32\% Sn i 15\% Zn w układzie bębnowym, jak również zawieszkowym, o technicznej nazwie Miralloy 2844. Do nakładania białego brązu (Cu-Sn-Zn) stosowano anody grafitowe, zanurzone w elektrolicie (kąpieli Miralloy 2844). Podobnie jak w dwóch poprzednich przypadkach stosunek pola powierzchni anody do katody wynosił 2:1, a zagwarantowanie równomiernej wymiany elektrolitu wymagało zastosowania ciągłego mieszania kąpieli ruchem obrotowym mieszadła magnetycznego z prędkością 60 obr/min. Maksymalna szybkość nakładania powłoki Cu-Sn-Zn wynosiła 0,12 $\mu \mathrm{m} / \mathrm{min}$ przy utrzymaniu stałej temperatury kąpieli wynoszącej $60^{\circ} \mathrm{C}$ oraz katodowej gęstości prądu równej 0,5 A/dm². Parametry pracy kąpieli Miralloy 2844 pracującej w układzie zawieszkowym przedstawiono w tablicy VII [11]. Zalecana maksymalna grubość powłoki Cu-Sn-Zn wynosi $5 \mu \mathrm{m}$.

\section{Powłoka niklowa (Ni chemiczny)}

Powłoka niklowa o średniej zawartości fosforu i technicznej nazwie SurTec832 przeznaczona jest do nanoszenia chemicznego (bezprądowego). Zlewkę szklaną wypełnioną elektrolitem SurTec832 o pH 5,0 podgrzewano do temperatury $88^{\circ} \mathrm{C}$ na oporowej płycie grzewczej o mocy 800 W z 5-stopniową regulacją temperatury. Po ogrzaniu elektrolitu do wymaganej temperatury umieszczono w nim próbkę, na którą naniesiona miała zostać powłoka. Próbki przygotowywano w taki sam sposób jak w przypadku nanoszenia wcześniej

Tablica V. Parametry pracy kąpieli cynkowej Envirozin 120 w układzie zawieszkowym [9]

Table V. The parameters of the zinc bath Envirozin 120 in the ticket system [9]

\begin{tabular}{|l|c|c|}
\hline Parametry pracy & Zakres & Optimum \\
\hline Zawartość cynku w kąpieli & $10 \div 14 \mathrm{~g} / \mathrm{dm}^{3}$ & $11 \mathrm{~g} / \mathrm{dm}^{3}$ \\
\hline Zawartość NaOH w kąpieli & $125 \div 145 \mathrm{~g} / \mathrm{dm}^{3}$ & $135 \mathrm{~g} / \mathrm{dm}^{3}$ \\
\hline Temperatura & \multicolumn{2}{|c|}{$25 \div 30^{\circ} \mathrm{C}$} \\
\hline Katodowa gęstość prądu & $2,0 \div 3,5 \mathrm{~A} / \mathrm{dm}^{2}$ \\
\hline Anodowa gęstość prądu & \multicolumn{2}{|c|}{$1,0 \div 2,0 \mathrm{~A} / \mathrm{dm}^{2}$} \\
\hline
\end{tabular}

Tablica VI. Parametry pracy kąpieli Enviralloy Ni 12-15 w układzie zawieszkowym [10]

Table VI. The parameters of the bath Enviralloy Ni 12-15 in the ticket system [10]

\begin{tabular}{|l|c|c|}
\hline \multicolumn{1}{|c|}{ Parametry pracy } & Zakres & Optimum \\
\hline Zawartość cynku w kąpieli & $6 \div 8 \mathrm{~g} / \mathrm{dm}^{3}$ & $1,1 \mathrm{~g} / \mathrm{dm}^{3}$ \\
\hline Zawartość niklu w kąpieli & $0,7 \div 1,3 \mathrm{~g} / \mathrm{dm}^{3}$ & $115 \mathrm{~g} / \mathrm{dm}^{3}$ \\
\hline Zawartość NaOH w kąpieli & $110 \div 120 \mathrm{~g} / \mathrm{dm}^{3}$ & $<80 \mathrm{~g} / \mathrm{dm}^{3}$ \\
\hline Zawartość węglanu sodowego w kąpieli & $20 \div 28^{\circ} \mathrm{C}$ \\
\hline Temperatura & \multicolumn{2}{|c|}{$1,5 \div 2,5 \mathrm{~A} / \mathrm{dm}^{2}$} \\
\hline Katodowa gęstość prądu & $1,0 \div 2,0 \mathrm{~A} / \mathrm{dm}^{2}$ \\
\hline Anodowa gęstość prądu & \multicolumn{2}{|c|}{} \\
\hline
\end{tabular}


Tablica VII. Parametry pracy kąpieli Miralloy 2844 w układzie zawieszkowym [11]

Table VII. The parameters of the bath Miralloy 2844 in the ticket system [11]

\begin{tabular}{|c|c|c|}
\hline Parametry pracy & Zakres & Optimum \\
\hline Zawartość miedzi w kąpieli & $7,5 \div 9,5 \mathrm{~g} / \mathrm{dm}^{3}$ & $8,5 \mathrm{~g} / \mathrm{dm}^{3}$ \\
\hline Zawartość cynku w kąpieli & $25 \div 40 \mathrm{~g} / \mathrm{dm}^{3}$ & $34 \mathrm{~g} / \mathrm{dm}^{3}$ \\
\hline Zawartość cyny w kąpieli & $0,3 \div 0,6 \mathrm{~g} / \mathrm{dm}^{3}$ & $0,5 \mathrm{~g} / \mathrm{dm}^{3}$ \\
\hline Zawartość wolnego cyjanku potasu w kąpieli & $45 \div 55 \mathrm{~g} / \mathrm{dm}^{3}$ & $50 \mathrm{~g} / \mathrm{dm}^{3}$ \\
\hline Zawartość $\mathrm{NaOH}$ w kąpieli & $25 \div 35 \mathrm{~g} / \mathrm{dm}^{3}$ & $30 \mathrm{~g} / \mathrm{dm}^{3}$ \\
\hline Temperatura & $58 \div 62^{\circ} \mathrm{C}$ & $60^{\circ} \mathrm{C}$ \\
\hline Katodowa gęstość prądu & $0,2 \div 0,7 \mathrm{~A} / \mathrm{dm}^{2}$ & $0,5 \mathrm{~A} / \mathrm{dm}^{2}$ \\
\hline Anodowa gęstość prądu & \multicolumn{2}{|c|}{$\max 1,0 \mathrm{~A} / \mathrm{dm}^{2}$} \\
\hline
\end{tabular}

Tablica VIII. Parametry pracy kąpieli SurTec832 w układzie zawieszkowym [12]

Table VIII. The parameters of the bath SurTec832 in the ticket system [12]

\begin{tabular}{|l|c|c|}
\hline \multicolumn{1}{|c|}{ Parametry pracy } & Zakres & Optimum \\
\hline Zawartość niklu w kąpieli & $4,9 \div 6,4 \mathrm{~g} / \mathrm{dm}^{3}$ & $6 \mathrm{~g} / \mathrm{dm}^{3}$ \\
\hline Zawartość fosforanu sodu w kąpieli & $26 \div 34 \mathrm{~g} / \mathrm{dm}^{3}$ & $30 \mathrm{~g} / \mathrm{dm}^{3}$ \\
\hline Temperatura & $85 \div 92^{\circ} \mathrm{C}$ & $88^{\circ} \mathrm{C}$ \\
\hline $\mathrm{pH}$ & $4,6 \div 5,4$ & 5,0 \\
\hline Katodowa gęstość prądu & & - \\
\hline Anodowa gęstość prądu & & - \\
\hline
\end{tabular}

opisanych powłok. Podczas nanoszenia powłoki $\mathrm{Ni}$ należało również mieszać elektrolit w odstępach czasowych wynoszących $20 \div 25$ s w ciągu $5 \div 10$ s. Parametry pracy kąpieli SurTec832 przedstawiono w tablicy VIII [12]. Do prób lutowania na powierzchnię miedzi M1E i stali niestopowej DC01 naniesiono warstwy Ni o grubości $20 \mu \mathrm{m}$.

Wszystkie opisane powyżej powłoki osadzały się na podłożu miedzianym M1E i stalowym DC01, tworząc szczelną i dobrze przylegającą warstwę.

Pomiarów grubości naniesionych powłok na podłoże miedziane M1E i stalowe DC01 dokonano przy użyciu urządzenia firmy Fischerscope typu XRAY XDL-B. Służy ono do pomiaru grubości powłok i badań składu metoda fluorescencji rentgenowskiej. Umożliwia ona pomiary bardzo skomplikowanych układów powłok bez stosowania wzorców kalibracyjnych z przewidywaną dokładnością pomiarową ( $\pm 1 \mu \mathrm{m})$ oraz zapewnia badanie składu chemicznego materiałów aż do 24 pierwiastków. Pomiar polega na tym, że strumień promieniowania rentgenowskiego bombarduje powłokę. Jego wysoka energia umożliwia mu penetrację i wywołanie fluorescencji zarówno powłoki, jak i podłoża. Grubość powłoki można wyznaczyć mierząc intensywność fluorescencji rentgenowskiej materiału powłoki - im większa intensywność fluorescencji tym większa grubość mierzonej powłoki [15]. Grubość uzyskanych warstw naniesionych na podłoże miedziane M1E oraz ze stali niestopowej DC01 przedstawiono w tablicy IX.

Nanoszenie powłoki $\mathrm{Ni}$ na powierzchnię stali nie jest zalecane ze względu na znaczną zawartość w kąpieli fosforu, dochodzącą do $8 \%$ wag. P, który w wyniku oddziaływania ze stalą podczas lutowania (szczególnie twardego) tworzy kruche fazy międzymetaliczne [13].
Tablica IX. Średnia grubość naniesionych powłok w zależności od czasu nakładania

Table IX. Average coating thickness plotted versus time application

\begin{tabular}{|c|c|c|c|}
\hline Powłoka & Podłoże & $\begin{array}{c}\text { Czas } \\
\text { osadzania } \\
\text { min. }\end{array}$ & $\begin{array}{c}\text { Średnia } \\
\text { grubość } \\
\text { powłoki, } \mu \mathrm{m}\end{array}$ \\
\hline \multirow{2}{*}{$\mathrm{Zn}$} & Cu M1E & \multirow{2}{*}{40} & 19,95 \\
\hline & Stal DC01 & & 19,97 \\
\hline \multirow{2}{*}{$\mathrm{Zn}-\mathrm{Ni}$} & Cu M1E & \multirow{2}{*}{120} & 15,93 \\
\hline & Stal DC01 & & 15,98 \\
\hline \multirow{2}{*}{$\begin{array}{c}\text { Cu-Sn- } \\
\text { Zn }\end{array}$} & Cu M1E & \multirow{2}{*}{90} & 5,03 \\
\hline & Stal DC01 & & 4,98 \\
\hline $\mathrm{Ni}$ & Cu M1E & 90 & 19,83 \\
\hline
\end{tabular}

\section{Badania zwilżalności i rozpływności naniesionych powłok lutami cynkowymi}

W celu określenia przydatności naniesionych warstw do procesów lutowania przeprowadzono próby ich zwilżalności i rozpływności lutami cynkowymi. Próby przeprowadzono na blachach o grubości 0,5 mm (+ grubość naniesionej warstwy) i wymiarach $50 \times 50 \mathrm{~mm}$. Do prób stosowano luty o masie $0,1 \mathrm{~g}$ pocięte na odcinki o długości ok. $1 \mathrm{~mm}$, które następnie pokrywano topnikiem o masie równej połowie masy lutu. Próbki ułożono na siatce pokrytej ceramiką umieszczonej na trójnogu i podgrzewano od dołu płomieniem propanowo-powietrznym przy użyciu palnika Bunsena. Od momentu stopienia lutu czas nagrzewania wynosił ok. 5 s [2, 4]. 


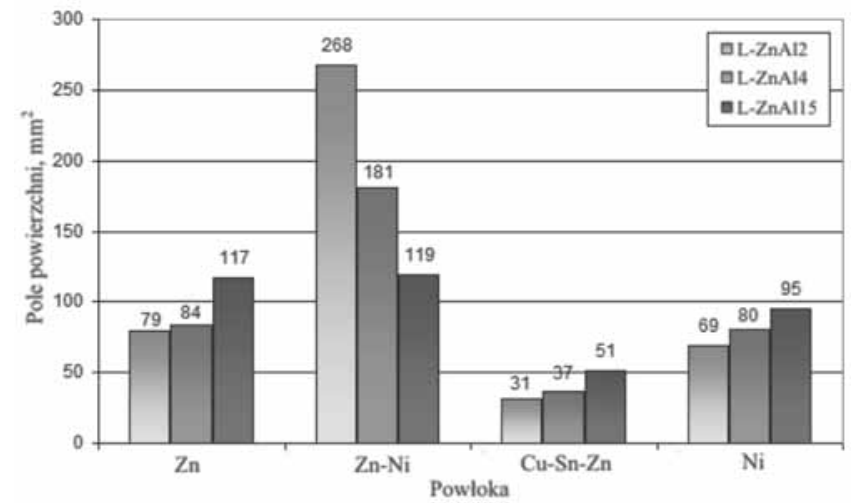

Rys. 3. Wyniki próby rozpływności lutów cynkowych na powierzchni badanych metali z naniesionymi powłokami

Fig. 3. Test results of flowing solder zinc on the surface of the tested metals with marked coatings

Do obliczania pól powierzchni rozpłynięcia się lutów cynkowych użyto programu optycznego DP - Soft Olympus do cyfrowej obróbki zdjęć z funkcją planimetrowania powierzchni. Wyniki pomiarów rozpływności lutów $\mathrm{Zn}$ na powierzchni badanych metali $\mathrm{z}$ naniesionymi warstwami przedstawiono $w$ tablicy $X$. Są to wartości średnie z pięciu pomiarów.

Na podstawie prób rozpływności lutów Zn na podłożach z naniesionymi galwanicznie warstwami do dalszych badań została wybrana powłoka stopowa $\mathrm{Zn}-\mathrm{Ni}$. Jest to spowodowane tym, że warstwa ta zapewnia najlepszą spośród stosowanych powłok poprawę lutowności pokrywanych materiałów (zwłaszcza miedzi M1E). Ponadto powłoka $\mathrm{Zn}-\mathrm{Ni}$, ze względu na niemal dziesięciokrotnie większą odporność na korozję w porównaniu z powłoką Zn oraz na działanie wysokich temperatur, jest obecnie najczęściej stosowaną powłoką w przemyśle motoryzacyjnym oraz w budowie sprzętu AGD. Na rysunku 3 przedstawiono porównanie rozpływności lutów $\mathrm{Zn}$ na podłożu miedzianym M1E $z$ naniesionymi warstwami.

Charakterystyczną cechą tej powłoki są malejące wraz ze wzrostem zawartości aluminium w lutach Zn pola powierzchni rozpływności. Jest to odwrotna sytuacja do tej, która ma miejsce $w$ przypadku rozpływności lutów cynkowych na powierzchni materiałów bez pokryć [4]. Tam na każdym z materiałów rozpływność rosła wraz ze wzrostem aluminium w lutach. Podobnie jest również w przypadku pozostałych powłok Zn, Cu-Sn-Zn oraz Ni.
Pomiarów kątów zwilżania dokonano na przekrojach poprzecznych wykonanych w połowie kropli rozpłyniętych lutów, a ich wyniki zamieszczono w tablicy XI. Na rysunku 4 przedstawiono porównanie zwilżalności podłoży z naniesioną warstwą Zn-Ni ze zwilżalnością podłoży bez warstwy. Są to wartości średnie z pięciu pomiarów.

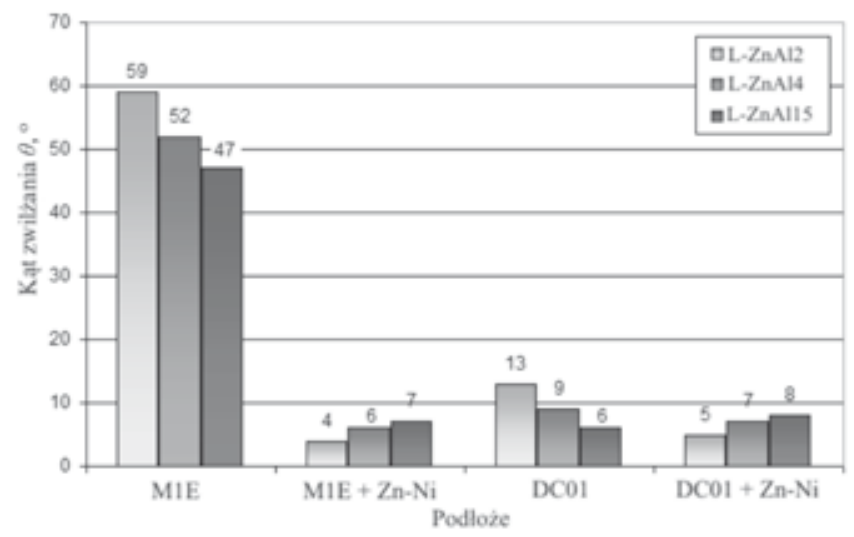

Rys. 4. Porównanie zwilżalności badanych podłoży w stanie surowym i z naniesioną warstwą $\mathrm{Zn}-\mathrm{Ni}$

Fig. 4. Comparison of the wettability of surfaces tested in the rough and deposited a layer of $\mathrm{Zn}-\mathrm{Ni}$
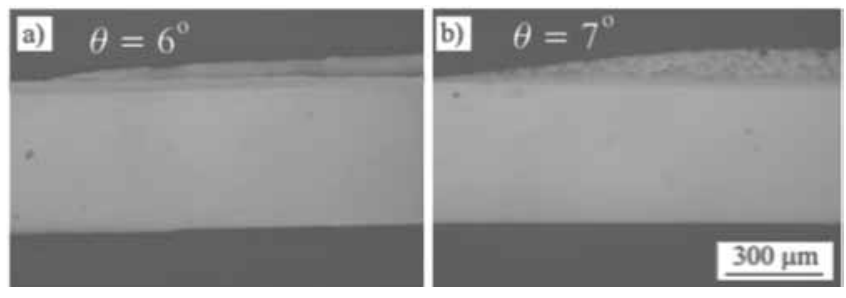

Rys. 5. Przykładowe zwilżanie lutem L-ZnAl4 powierzchni: stali niestopowej DC01 (a) i miedzi (b) z naniesioną $16 \mu \mathrm{m}$ warstwą Zn-Ni Fig. 5. Examples of wetting of solder L-ZnAl4 surface: non-alloy steel DC01 (a) and copper (b) of $16 \mu$ m layer deposited Zn-N

Tablica XI. Wyniki pomiarów zwilżalności lutów cynkowych na podłożach z naniesioną warstwą Zn-Ni

Table XI. The results of measurements of zinc solder wettability on substrates coated with the layer of $\mathrm{Zn}-\mathrm{Ni}$

\begin{tabular}{|c|c|c|c|}
\hline \multirow{2}{*}{$\begin{array}{c}\text { Oznaczenie } \\
\text { lutu }\end{array}$} & \multirow[b]{2}{*}{ Powłoka } & \multicolumn{2}{|c|}{ Kąt zwilżania, o } \\
\hline & & $\begin{array}{l}\text { Miedź } \\
\text { M1E }\end{array}$ & Stal DC01 \\
\hline L-ZnAl2 & \multirow{3}{*}{$\mathrm{Zn}-\mathrm{Ni}$} & 4 & 5 \\
\hline L-ZnAl4 & & 6 & 7 \\
\hline L-ZnAl15 & & 7 & 8 \\
\hline
\end{tabular}

Tablica X. Wyniki pomiarów rozpływności lutów cynkowych na powierzchni badanych metali z naniesionymi powłokami Table X. The results of measurements of flowing solder zinc on the surface of the tested metals with marked coatings

\begin{tabular}{|c|c|c|c|c|c|c|c|c|c|}
\hline \multirow{3}{*}{ Lut } & \multicolumn{9}{|c|}{ Pole powierzchni rozpłynięcia się lutu, $\mathrm{mm}^{2}$} \\
\hline & \multirow{2}{*}{ Topnik } & \multicolumn{2}{|c|}{$\mathrm{Zn}$} & \multicolumn{2}{|c|}{$\mathrm{Zn}-\mathrm{Ni}$} & \multicolumn{2}{|c|}{$\mathrm{Cu}-\mathrm{Sn}-\mathrm{Zn}$} & \multicolumn{2}{|c|}{$\mathrm{Ni}$} \\
\hline & & M1E & DC01 & M1E & DC01 & M1E & $\mathrm{DC} 01$ & M1E & DC01 \\
\hline L-ZnAl2 & \multirow{3}{*}{$192 \mathrm{NX}$} & 79 & 73 & 268 & 276 & 31 & 57 & 69 & - \\
\hline L-ZnAl4 & & 84 & 80 & 181 & 185 & 37 & 66 & 80 & - \\
\hline L-ZnAl15 & & 117 & 124 & 119 & 127 & 51 & 100 & 95 & - \\
\hline
\end{tabular}


Uzyskane wyniki są zadowalające, o czym świadczą małe kąty zwilżania, których średnia wartość niezależnie od rodzaju użytego lutu cynkowego nie przekracza $10^{\circ}$. Na szczególną uwagę zasługuje znaczna poprawa zwilżalności podłoża miedzianego, o czym świadczą wielokrotnie mniejsze kąty zwilżania. W przypadku podłoża miedzianego bez warstwy Zn-Ni wartość tego kąta wynosiła $47 \div 59^{\circ}$ w zależności od zawartości Al w lutach Zn [4]. Na rysunku 5 przedstawiono przykładowe zwilżanie powierzchni stali DC01 i miedzi z naniesioną na ich powierzchnię warstwą Zn-Ni.

\section{Badania metalograficzne i pomiary mikrotwardości}

Poprawne wykonanie złącza rurkowego aluminium $z$ miedzią, często stosowanego $w$ instalacjach chłodniczych i klimatyzacyjnych, przy użyciu lutów Zn jest w praktyce znacznie utrudnione. Jak podano w pracy [4], trudności te wynikają z braku dobrej zwilżalności spoiwami Zn miedzi, co wpływa na wydłużenie czasu lutowania oraz niecałkowite wypełnienie szczeliny lutowniczej ciekłym spoiwem. Dłuższy czas lutowania

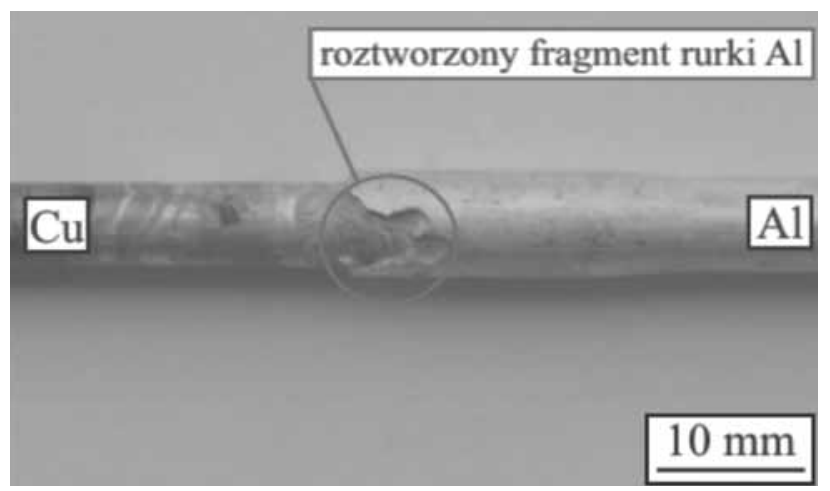

Rys. 6. Roztworzony przez lut L-ZnAl4 fragment rurki aluminiowej w złączu Al-Cu [4]

Fig. 6. Digested by L-ZnAl4 solder part of aluminum pipe into the joint Al-Cu [4]

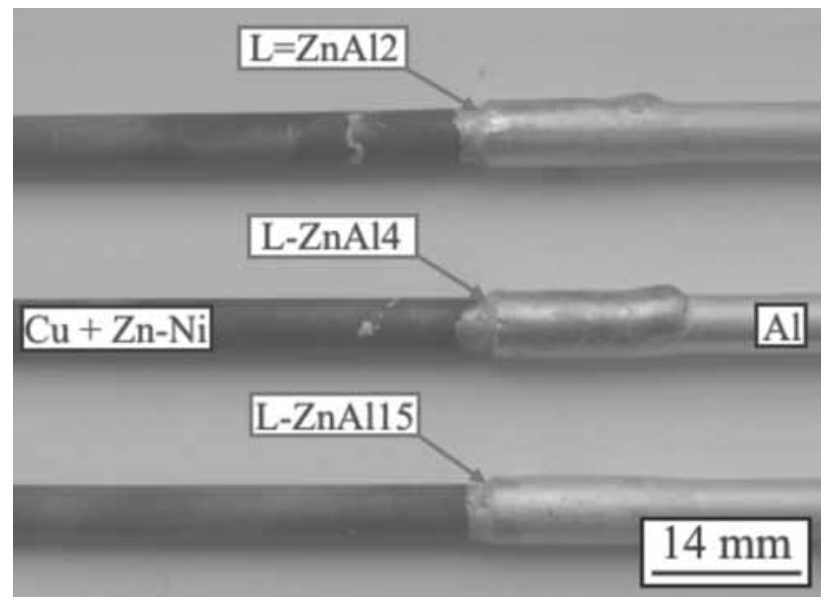

Rys. 7. Połączenia Al-Cu z naniesioną na powierzchnię miedzi warstwą Zn-Ni o grubości $16 \mu \mathrm{m}$, wykonane lutami cynkowymi

Fig. 7. Joints Al-Cu deposited on the surface of the copper layer of $\mathrm{Zn}-\mathrm{Ni}$ thickness of $16 \mu \mathrm{m}$, made by zinc solders powoduje też roztwarzanie aluminiowej rurki o grubości ścianki 0,9 mm przez spoiwa cynkowe (rys. 6) [4]. Na rysunku 6 pokazano złącze, w którym w rurkę aluminiową o średnicy $8,0 \times 0,9 \mathrm{~mm}$ wlutowano rurkę miedzianą o średnicy $6,0 \times 1,0 \mathrm{~mm}$. Połączenia takie stosowane są do połączenia parownika ze sprężarką w chłodziarkach i chłodziarko-zamrażarkach.

Naniesienie na powierzchnię rurki miedzianej warstwy Zn-Ni o grubości $16 \mu \mathrm{m}$ przyczynia się do lepszego jej zwilżania spoiwami Zn. Powoduje to znaczne ułatwienie procesu lutowania oraz brak widocznych na powierzchni rurki aluminiowej miejsc roztworzonych przez luty cynkowe (rys. 7).

Otrzymane złącza charakteryzują się również niemal całkowitym wypełnieniem szczeliny lutowniczej na całej długości złącza. Naniesienie warstwy Zn-Ni o grubości $16 \mu \mathrm{m}$ na powierzchnię rurki miedzianej powoduje jednak zmniejszenie szerokości szczeliny lutowniczej z 0,1 do $0,084 \mathrm{~mm}$, co może utrudnić wydostanie się topnika $z$ lutowiny.

Wykonano również połączenia zakładkowe aluminium EN AW-1050A z miedzią M1E i stalą DC01 z naniesioną na ich powierzchnię warstwą Zn-Ni o grubości $16 \mu \mathrm{m}$. Na rysunku 8 pokazano przekroje wykonanych połączeń zakładkowych. Szerokość szczeliny lutowniczej wynosiła $0,2 \mathrm{~mm}$. Otrzymane połączenia charakteryzują się dobrym wypełnieniem szczeliny lutowniczej na całej długości złącza.

Na przekrojach poprzecznych, pokazanych na rysunku 9, dokonano pomiarów mikrotwardości metodą Vickersa przy obciążeniu penetratora wynoszącym $25 \mathrm{G}$, zgodnie z PN-EN ISO 6507-1:2007 (rys. 8) [14].

Naniesiona na powierzchnię miedzi i stali niestopowej warstwa $\mathrm{Zn}-\mathrm{Ni}$ - jak zakładano - hamuje i znacznie ogranicza tworzenie się faz międzymetalicznych na granicy połączenia z lutem. Świadczy o tym niemal trzykrotnie mniejsza twardość w strefie na granicy połączenia w porównaniu z połączeniami bez naniesionej warstwy Zn-Ni. Twardość strefy reakcyjnej w połączeniach bez powłoki $\mathrm{Zn}-\mathrm{Ni}$ w obydwu przypadkach przekraczała wartość 500 HV0,025 [4]. Warstwa Zn-Ni o grubości $16 \mu \mathrm{m}$ zmniejsza twardość tej strefy do niespełna 200 HV0,025, co nie stanowi zagrożenia dla funkcjonalności połączeń lutowanych.

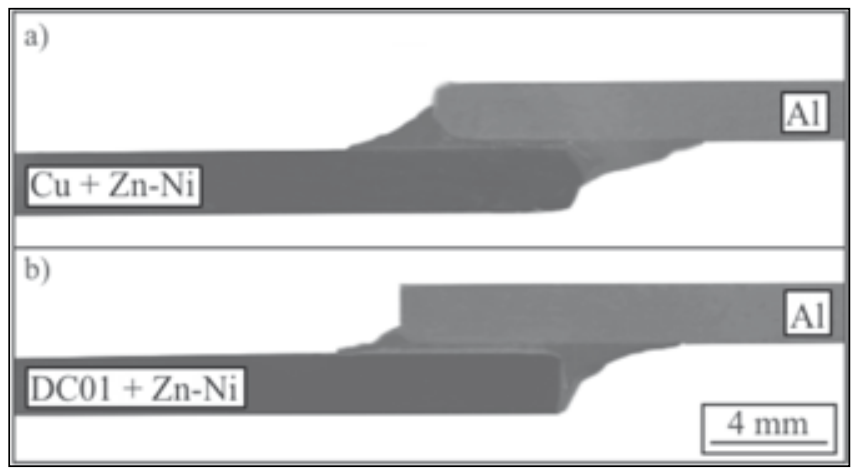

Rys. 8. Złącza zakładkowe: Al-Cu + warstwa Zn-Ni (a) i Al-DC01 + warstwa $\mathrm{Zn}-\mathrm{Ni}(\mathrm{b})$ wykonane lutem L-ZnAl4

Fig. 8. Muff joints: Al-Cu + coat Zn-Ni (a) and Al-DC01 + coat Zn-Ni (b) made by L-ZnAl4 solder 

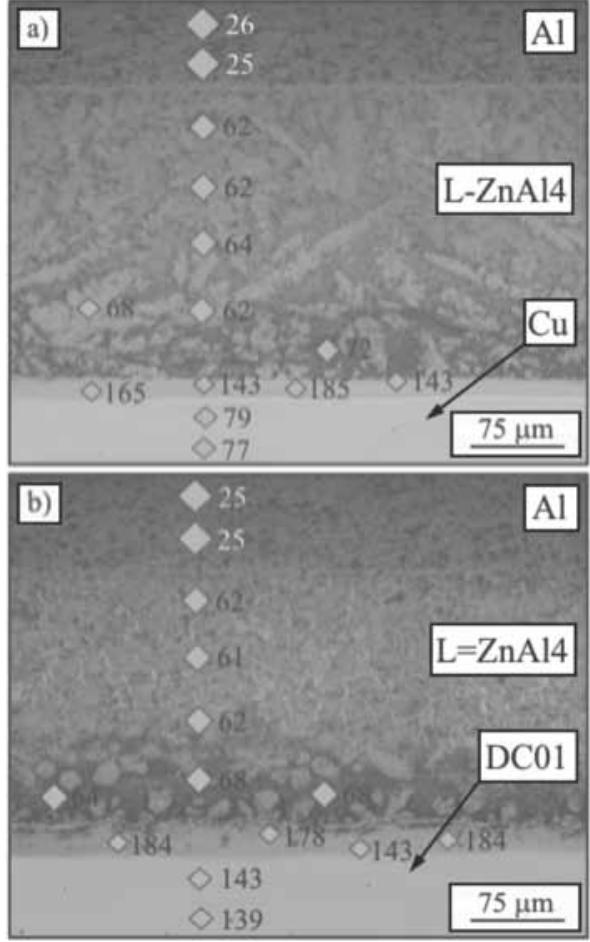

Rys. 9. Rozkład mikrotwardości HV0,025 w złączach Al-Cu + warstwa Zn-Ni (a) i Al-DC01 + warstwa Zn-Ni (b), wykonane lutem L-ZnAl4

Fig. 9. The distribution of microhardness $\mathrm{HV0}, 025$ in joints $\mathrm{Al}-\mathrm{Cu}+$ coat Zn-Ni (a), Al-DC01 + coat Zn-Ni (b), made by L-ZnAl4 solder

\section{Statyczna próba ścinania różnoimiennych złączy lutowanych}

Do statycznej próby ścinania różnoimiennych połączeń lutowanych przygotowano próbki przedstawione na rysunku 10, które wykonano przez nagrzewanie płomieniem propanowo-powietrznym [4]. Połączenia lutowane ścinano na maszynie wytrzymałościowej firmy Instron - model 3369, używając uchwytu z wkładkami dystansowymi. Prędkość przesuwu belki poprzecznej maszyny wynosiła $2 \mathrm{~mm} / \mathrm{min}$, a zakres obciążeń do $50 \mathrm{kN}$. Wykonano dwa rodzaje różnoimiennych połączeń lutowanych: Al-Cu + warstwa $\mathrm{Zn}-\mathrm{Ni}, \mathrm{Al}-\mathrm{DC01}+$ warstwa $\mathrm{Zn}-\mathrm{Ni}$. Ze względu na nieznaczny wpływ zawartości Al w lutach Zn na wytrzymałość mechaniczną połączeń, próbki przygotowano stosując jedynie lut L-ZnAl4.

W przypadku połączeń typu $\mathrm{Al}-\mathrm{Cu}+$ warstwa $\mathrm{Zn}-\mathrm{Ni}$ szerokość zakładki wynosiła $5,0 \mathrm{~mm}$, tak jak w przypadku połączeń $\mathrm{Al}-\mathrm{Cu}$ bez naniesionej warstwy Zn-Ni. Zerwanie połączenia następowało $\mathrm{w}$ aluminium $\mathrm{w}$ strefie wpływu ciepła, przy wartości $73 \div 76 \mathrm{MPa}$ (rys. 11). Podjęto próbę zmniejszenia o połowę szerokości zakładki z 5,0 mm do $2,5 \mathrm{~mm}$. W takim przypadku następowało adhezyjne zerwanie połączenia od strony miedzi (rys. 12). Średnia wartość wytrzymałości na ścinanie w tym przypadku wynosi $54,5 \mathrm{MPa}$ i jest ona ponad dwa razy większa niż w przypadku połączeń Al-Cu bez warstwy Zn-Ni o dwukrotnie większej szerokości zakładki (24,6 MPa) [4].

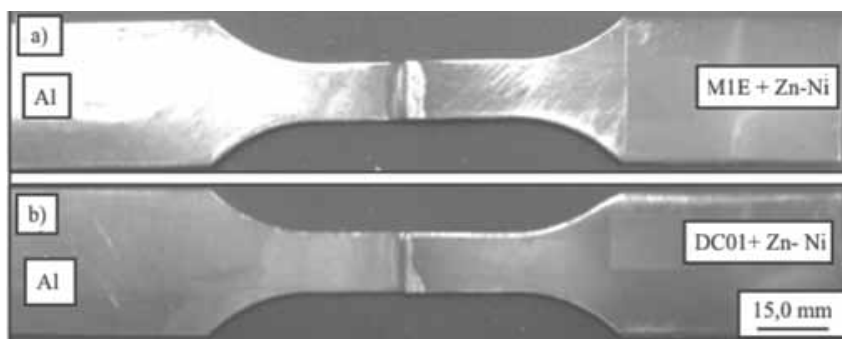

Rys. 10. Przykładowe próbki do statycznej próby ścinania: Al-M1E + $\mathrm{Zn}-\mathrm{Ni}$ (a) i Al-DC01 + ZnNi (b) [4]

Fig. 10. Examples of samples to the static shear test: Al-M1E + $\mathrm{Zn}-\mathrm{Ni}$ (a) and Al-DC01 + ZnNi (b) [4]

W celu upewnienia się, w którym obszarze doszło do zniszczenia połączenia przeprowadzono powierzchniową analizę EDS (Energy Dispersive Spectrometry) przy użyciu skaningowego mikroskopu elektronowego (Scanning Electron Microscopy, SEM) firmy Hitachi (rys. 13).

Na powierzchni złomu od strony miedzi, po statycznej próbie ścinania, występuje w przeważającej ilości $\mathrm{Zn}$, nie stwierdzono obecności miedzi na rozkładzie powierzchniowym. Rozdzielenie połączenia wystąpiło w lutowinie na osnowie cynku w pobliżu naniesionej warstwy galwanicznej (rys. 14).

Połączenia typu Al-DC01 + warstwa Zn-Ni wykonano, zachowując taką samą szerokość zakładki $(2,5 \mathrm{~mm})$ [4] jak w przypadku połączeń bez naniesionej warstwy Zn-Ni. W trzech na pięć przypadków zerwanie nastąpiło

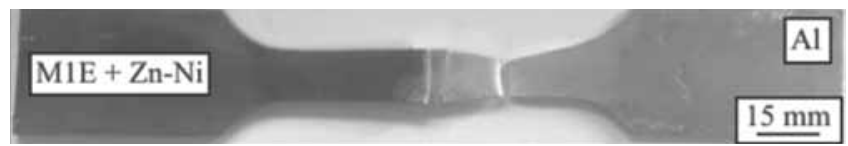

Rys. 11. Zerwanie połączenia Al-L-ZnAl4-M1E + Zn-Ni w aluminium w strefie wpływu ciepła przy szerokości zakładki wynoszącej $5,0 \mathrm{~mm}$ Fig. 11. The interruption of the joint Al-L-ZnAl4-M1E $+\mathrm{Zn}-\mathrm{Ni}$ in aluminum in the heat-affected zone at the width of the path of $5,0 \mathrm{~mm}$

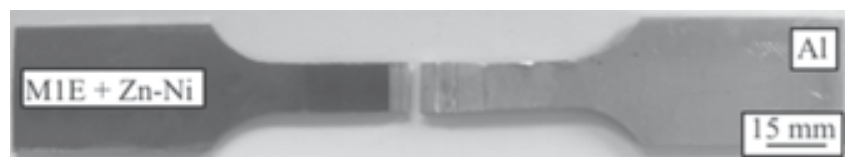

Rys. 12. Adhezyjne zerwanie połączenia Al-L-ZnAl4-M1E + Zn-Ni od strony miedzi przy szerokości zakładki wynoszącej $2,5 \mathrm{~mm}$

Fig. 12. Adhesive breaking joints Al-L-ZnAl4-M1E + Zn-Ni from copper side at the width of the path of $2,5 \mathrm{~mm}$

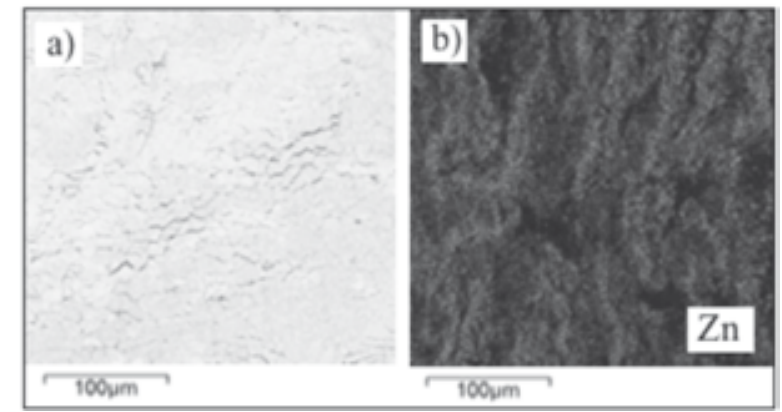

Rys. 13. Powierzchnia próbki miedzianej M1E + warstwa Zn-Ni po statycznej próbie ścinania (a), rozkład Zn (b)

Fig. 13. Surface of copper sample M1E + coat $\mathrm{Zn}-\mathrm{Ni}$ after the static shear test (a), Zn distribuation (b) 
w aluminium w strefie wpływu ciepła przy wartości w zakresie 74,0 $\div 76,5 \mathrm{MPa}$ (rys. 15a). W dwóch przypadkach zniszczenie złącza nastąpiło w wyniku dekohezji lutowiny, a wartość wytrzymałości na ścinanie wynosiła odpowiednio 65,3 i 64,9 MPa (rys. 15 b).

W celu dokładnego ustalenia umiejscowienia złomu przeprowadzono powierzchniową analizę przełomu EDS (rys. 16). W przypadku połączeń typu Al-DC01 również nie nastąpiło oderwanie się warstwy $\mathrm{Zn}-\mathrm{Ni}$ od podłoża stalowego, o czym świadczy występowanie na powierzchni złomu głównie $\mathrm{Zn}$ i Al. Potwierdza to również widok przekroju poprzecznego próbki po statycznej próbie ścinania (rys. 17).

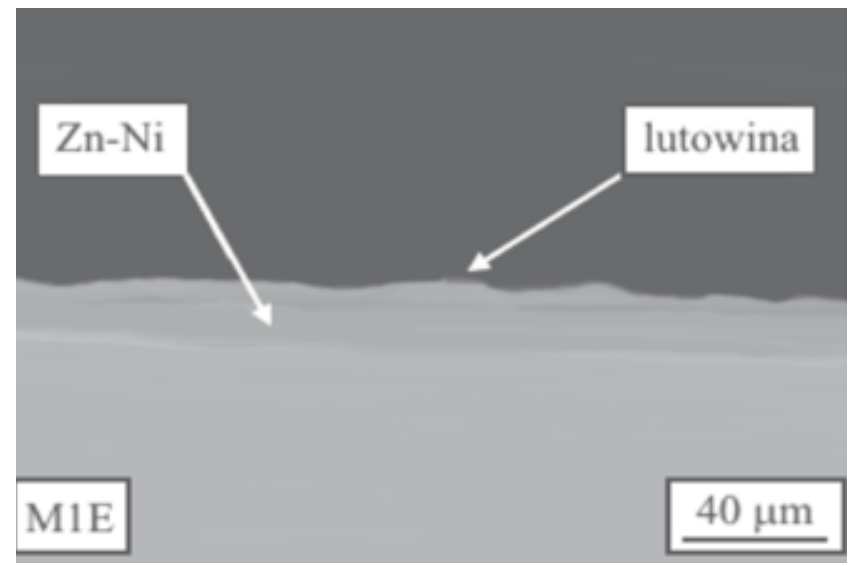

Rys. 14. Przekrój poprzeczny próbki miedzianej z naniesioną warstwą Zn-Ni po statycznej próbie ścinania

Fig. 14. The cross-section copper sample with apply coat Zn-Ni after the the static shear test

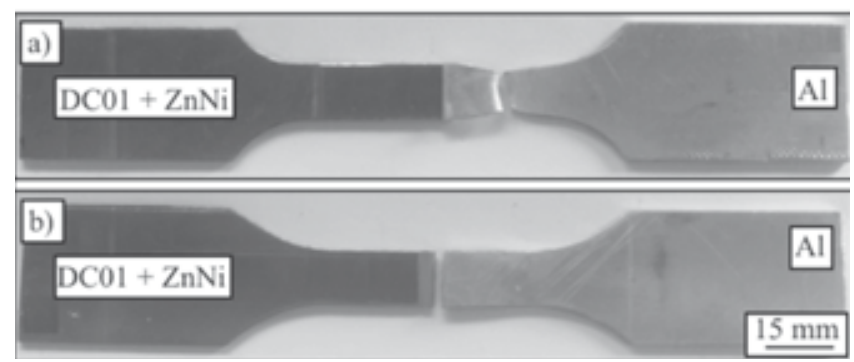

Rys. 15. Zerwanie połączenia Al-L-ZnAl4-DC01 + Zn-Ni w aluminium w strefie wpływu ciepła (a) i dekohezja lutowiny (b), przy szerokości zakładki wynoszącej $2,5 \mathrm{~mm}$

Fig. 15. The interruption of the joints Al-L-ZnAl4-DC01 + Zn-Ni in aluminum in the heat-affected zone (a) and cohesive breaking soldered joint (b), at the width of the path of $2,5 \mathrm{~mm}$

\section{Wnioski}

$\mathrm{Na}$ podstawie przeprowadzonych badań można sformułować następujące wnioski:

1. Naniesienie warstwy Zn-Ni o grubości $16 \mu \mathrm{m}$ na powierzchnię miedzi powoduje znaczną poprawę jej zwilżalności i rozpływności na jej powierzchni lutów cynkowych.

2. Połączenia lutowane aluminium z miedzią z naniesioną na jej powierzchnię warstwą Zn-Ni charakteryzują się dobrą estetyką, bez widocznych miejsc roztworzonych przez luty cynkowe oraz dobrym wypełnieniem szczeliny lutowniczej na całej długości złącza.
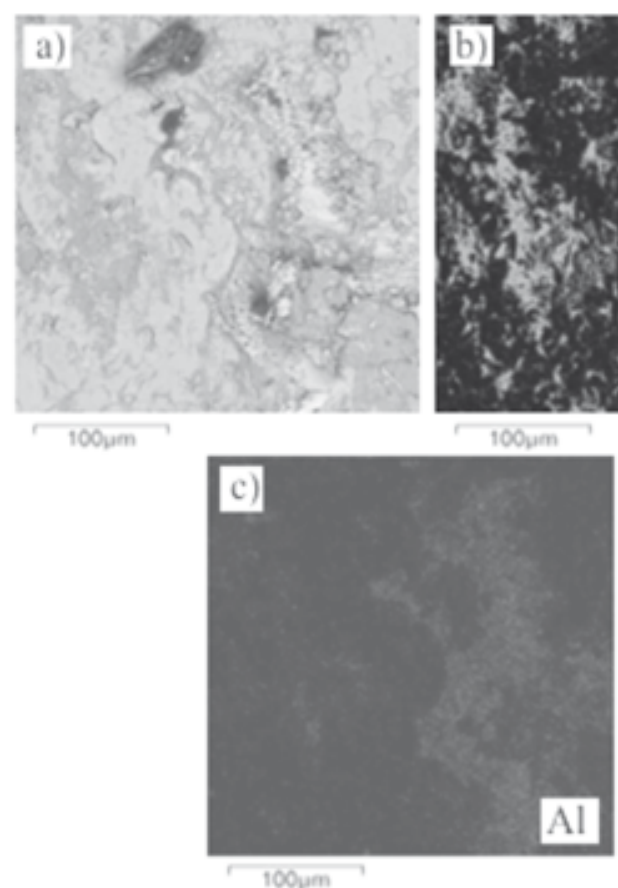

Rys. 16. Powierzchnia próbki stalowej DC01 + warstwa $\mathrm{ZnNi}$ po statycznej próbie ścinania (a), rozkład pierwiastków: Zn (b) i Al (c)

Fig. 16. Surface of non-alloy steel sample DC01 + coat Zn-Ni after the static shear test (a), elements distribuation: $\mathrm{Zn}(\mathrm{b})$ and $\mathrm{Al}(\mathrm{c})$

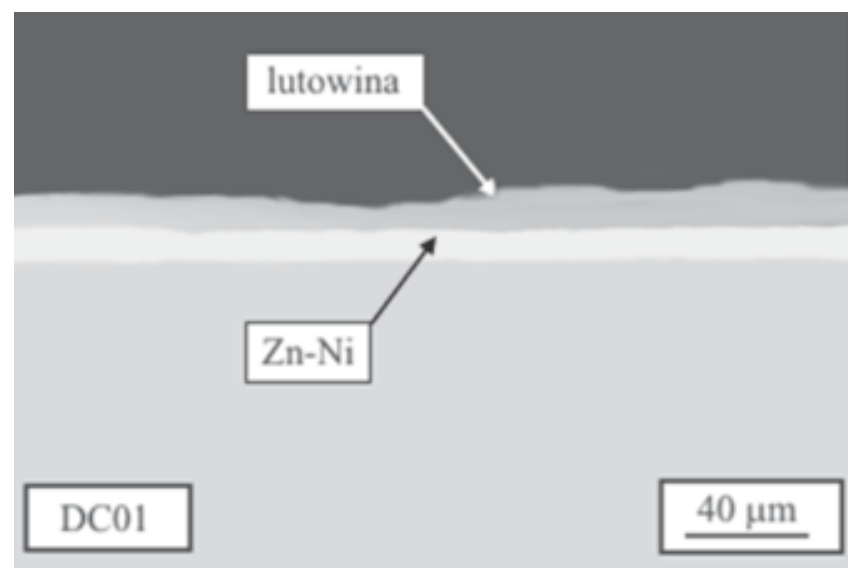

Rys. 17. Przekrój poprzeczny próbki stalowej DC01 z naniesioną warstwą Zn-Ni po statycznej próbie ścinania

Fig. 17. The cross-section non-alloy steel sample DC01 with apply coat $\mathrm{Zn}-\mathrm{Ni}$ after the the static shear test
3. Warstwa Zn-Ni naniesiona na powierzchnię miedzi i stali niestopowej skutecznie ogranicza tworzenie się faz międzymetalicznych na granicy połączenia z lutami cynkowymi, nie doprowadzając do powstania twardej strefy reakcyjnej.

4. Naniesienie warstwy Zn-Ni na powierzchnię miedzi powoduje ponad dwukrotny wzrost wytrzymałości na ścinanie połączeń lutowanych z aluminium. Zniszczenie połączenia lutowanego $z$ aluminium występowało w materiale rodzimym (Al) w strefie wpływu ciepła lub na skutek dekohezji w lutowinie. 


\section{Literatura}

[1] Różański M.: Wpływ dodatku tytanu w spoiwach cynkowych na zwilżalność powierzchni i właściwości mechaniczne połączeń lutowanych aluminium w gat. EN AW - 1050, Przegląd Spawalnictwa, nr 2/2013, s. $19-23$.

[2] Mirski Z., Granat K., Drzeniek H., Piwowarczyk T., Wojdat T.: Lutowanie miękkie aluminium z miedzią, Przegląd Spawalnictwa, nr 11/2009, s. $15-19$.

[3] Mirski Z., Granat K., Drzeniek H., Piwowarczyk T., Wojdat T.: Badanie zwilżalności lutów cynkowych na powierzchni aluminium i innych metali, Przegląd Spawalnictwa, nr 9/2010, s. $48-53$.

[4] Mirski Z., Wojdat T.: Połączenia lutowane aluminium z miedzią, stalą niestopową i stopową spoiwami cynkowymi, Przegląd Spawalnictwa, nr 4/2013, s. 2-8.

[5] PN-H-82120:1977: Miedź - Gatunki.

[6] PN EN10130:2009 Wyroby płaskie walcowane na zimno ze stali niskowęglowych do obróbki plastycznej na zimno - Warunki techniczne dostawy.
[7] PN EN 573-3:2010 Aluminium i stopy aluminium - Skład chemiczny i rodzaje wyrobów przerobionych plastycznie - Część 3: Skład chemiczny i rodzaje wyrobów.

[8] PN EN ISO 3677:2007 Spoiwa do lutowania miękkiego, twardego i lutospawania -- Oznaczenie.

[9] KTM MacDermid-Polska, Envirozin 120, katalog 2009.

[10] KTM MacDermid-Polska Sp. z o.o. Enviralloy Ni 12 - 15. Powłoka stopowa cynk - nikiel, katalog 2009.

[11] UMICORE BPP: Miralloy 2844 - biały brąz, katalog 2010.

[12] SURTEC POLSKA Sp. z o.o.: Nikiel chemiczny o średniej zawartości fosforu - SurTec832, katalog 2010.

[13] Prasałek A.: Lutowanie beztopnikowe miedzi ze stalą X6CrNiTi18-10 spoiwem CP 102 (L-Ag15P), Rozprawa doktorska, Instytut Technologii Maszyn i Automatyzacji Politechniki Wrocławskiej, Wrocław 2008.

[14] www.castolin.com

[15] www.tegal.pl
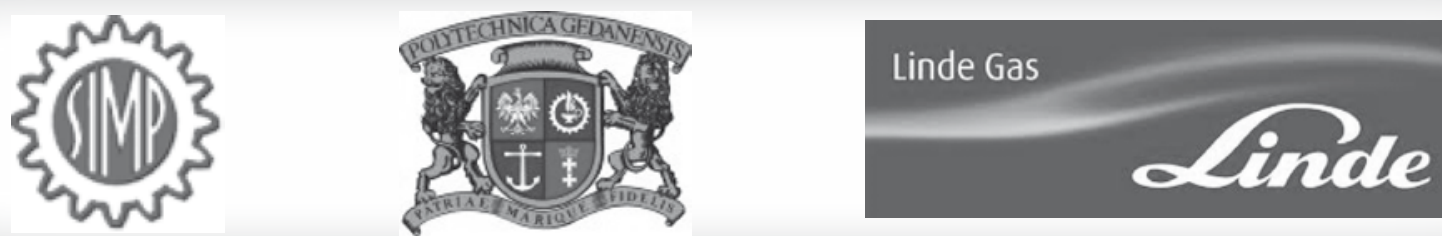

Mamy przyjemność zaprosić Państwa do uczestnictwa w:

\section{NAUKOWO-TECHNICZNEJ KONFERENCJI SPAWALNICZEJ pod hasłem:}

\section{SPAWALNICTWO W TRZECH ŻYWIOŁACH: ZIEMIA - WODA - POWIETRZE}

organizowanej w dniach 14-16 października 2013 r. w Gdańsku-Sobieszewie przez:

\section{Zakład Inżynierii Spajania Politechniki Gdańskiej, SIMP Oddział w Gdańsku, Linde Gaz Polska}

Konferencja odbędzie się w Ośrodku Wypoczynkowym „Orle” położonym na Wyspie Sobieszewskiej niedaleko ujścia Wisły do Zatoki Gdańskiej. W czasie konferencji przedstawione zostaną najnowsze osiągnięcia naukowe i techniczne z zakresu spawalnictwa. W programie konferencji przewidziane są również wycieczki techniczne oraz warsztaty.

dr hab. inż. Jerzy Łabanowski:

dr inż. Dariusz Fydrych:
Bliższych informacji udzielają:

tel.: 583472 366;

jlabanow@pg.gda.pl

tel.: 583486321 ;

dfydrych@mech.pg.gda.pl

Politechnika Gdańska, Wydział Mechaniczny, Zakład Inżynierii Spajania, ul. Narutowicza 11/12, 80-233 Gdańsk, http://www.konferencjaspawalnicza.pl/ 